\title{
COMMENT
}

DOI: $10.1057 /$ s41599-017-0062-8

\section{A Portuguese exception to right-wing populism}

\author{
Rodrigo Quintas da Silva ${ }^{1}$
}

\begin{abstract}
Many European countries have witnessed the rise of right-wing (nativist and authoritarian) populist parties over the last few years, which have gained significant votes and sometimes threatened the position of traditional parties. In Portugal, however, right-wing populism has failed to gain electoral support, and the populist discourse is scarcely found in Portuguese politics. In this comment, we offer four tentative hypotheses that explain why right-wing parties with a populist discourse are not present in Portugal: low levels of Eurospecticism, low immigration rates, lack of political space to develop, and lower engagement in communicating that same populism. We conclude that these dynamics create a special balance, and a rather specific political situation in Portugal that does not facilitate the spread of right-wing populism. This balance, we also argue, may be compromised if any of these dynamics suddenly change, potentially paving the way for right-wing populists in Portugal to achieve more political prominence.
\end{abstract}

\footnotetext{
${ }^{1}$ Independent researcher, Lisboa, Portugal. Correspondence and requests for materials should be addressed to R.S. (email: rodrigo.rgqs@hotmail.com)
} 


\section{Right-wing populism: what do we mean?}

$\mathrm{n}$ the last few years, right-wing populist parties have been receiving increased support in some European countries.

Marine Le Pen, Geert Wilders, Viktor Órban, Norbert Hofer and Nigel Farage have personified the rise of right-wing populism in Europe. However, populism itself is one of the most complex concepts to define in political science. The main literature agrees, however, on two important elements. The first claims that the government should act according to the will of the people (Albertazzi and McDonnell, 2008; Jagers and Walgrave, 2007; Mudde, 2004, 2007; Taggart, 2000). This "people", as Taggart (2000) stresses, is not the entire national population, but rather a section of the population, regarded as "virtuous" and pure. The second element concerns the inability of the government, or the political establishment, to represent the people's interests, due to its reputation for publicly exposed corruption. The role played by the populist leader would be to free the people from the distorted politics practiced by the political elite. As Mudde (2004, p 543) simplifies, populism is then "an ideology that considers society to be ultimately separated into two homogeneous and antagonistic groups, 'the pure people' vs. 'the corrupt elite', and which argues that politics should be an expression of the volonté générale (general will) of the people."

In order to further contextualize this comment, it is also essential to understand the "chameleonic quality" (Taggart, 2000) of populism. Michael Freeden (1996) suggested that there are some ideologies which can be combined with other main ideologies. Populism, as the literature shows, is one example of those (Albertazzi and McDonnell, 2008; Jagers and Walgrave, 2007; Lucardie and Voerman, 2012; Mudde, 2004; Stanley, 2008; Taggart, 2000). One must always take into consideration populism's positioning on the right-left spectrum (Huber and Schimpf, 2017; Otjes and Louwerse, 2015, p 63). Hence, populism does not exist alone, but is linked to other political ideologies.

In this context, populist parties are labeled "right-wing" if nativism and authoritarianism are their most important commitments (Mudde, 2007). The "people", in this context, are the national habitants of the country, while non-natives are regarded as a threat to the country (Mudde, 2007).

\section{The radical right in Portugal}

In Portugal, the radical right has not had the opportunity to develop with significant importance since the revolution that ended the dictatorship on the 25 April 1974 (Marchi, 2013). Since 1974, the date of the democratic revolution, "the various nationalist factions, which were rather fragmented during the final years of the deposed regime, were unwilling to coalesce around a shared project. Instead, these factions opted to organize autonomously into a handful of small parties" (Marchi, 2013, p 133). During the 1980s and 1990s, the Portuguese radical right suffered from this division, but by the 2000s, "radical activists were eager to try to gain a foothold in the political arena and take advantage of the winds of populism, identity politics, and protest that were beginning to sweep across Europe in the new millennium" (Marchi, 2013, p 135).

Nowadays, the radical right in Portugal is represented by the National Renovator Party (Partido National Renovador, PNR), that in the parliamentary election of 2015 (during the economic crisis), obtained only $0.5 \%$ of the popular vote (27,269 votes; Ministério da Administração Interna, 2015). The PNR's agenda is mainly focused on identity and nativist issues (especially against immigration; see, e.g., Marchi, 2013, p 141), fitting in with the right-wing criteria presented by Mudde (2007).

In Portugal, no other party in parliament includes antiimmigration policies in its program, and only two parties defend the exit or reform of the European Union or the Euro Zone: the Portuguese Communist Party (Partido Comunista Português, PCP) and the Left Bloc (Bloco de Esquerda, BE), both left-wing parties (for a better overview of left-wing populism, see March, 2007, 2011).

Naturally, a more detailed academic analysis is required in order to fully understand the lack of force of right-wing populism in Portugal. However, there are some variables that may help us to understand the occurrence of this phenomenon. In this comment I touch upon four elements present in European right-wing populism: pro (or anti) Euroscepticism, immigration, national party composition, and the communication skills of its campaign.

\section{The immigration factor}

European right-wing populist parties place an emphasis on antiimmigration, an important theme in their discourse. The entrance of immigrants and refugees in some of the most powerful countries in the continent is regarded by European right-wing populists as a threat to the Western model of civilization. The European radical right constantly uses the wording "threat" and "invasion" to mention the influx of immigrants-sometimes with a religious factor involved. Marine Le Pen, Geert Wilders, Nigel Farage, and Viktor Órban use this rhetoric to their own conclusions and judgments.

The same situation is not found in Portugal, which has a lower immigration rate than the United Kingdom, Germany, or France. Currently, in Portugal, there are 500,000 Muslim individuals, the majority of them from former colonies such as Mozambique, India or Guinea Bissau; but also from Bangladesh, Senegal, and Morocco (Público, 2015). Generally speaking, Portugal registered in 2015 a gross immigration rate of less than 3\%. This number is inferior when compared to other countries like France (5.5\%), United Kingdom (9.7\%), Holland (9.9\%), Germany (18.9\%), or Austria (19.3\%) (Pordata, 2017a)—where right-wing populism registered a significant increase.

The financial crisis of 2009 hit the immigrant population with special relevance (Borges, 2015), which in some cases registered a higher unemployment rate than that of nationals (Pereira and Esteves, 2017, p 149). This led to a decline in the immigration rates. Although immigration rates have been slowly recovering (Serviço de Estrangeiros e Fronteiras, 2016, p 10), the most striking reasons for this rise are the general sense of security and fiscal security that Portugal offers, which primarily benefit immigrants from Western Europe (Público, 2016).

If we attend to refugees in particular (one of the main targets of right-wing populist discourse, including in Portugal), the rates are still low when compared to other Western European countries due to bureaucracy and personal choice of refugees (Expresso, 2015). As Luís Gouveia, adjunct national director of the Portuguese Service for Foreigners and Borders (Serviço de Estrangeiros e Fronteiras) in 2015 affirmed, Portugal is not the first choice for people requesting asylum and has little history of attributing that status to the requesters (Expresso, 2015).

Moreover, and as aforementioned, the majority of immigration to Portugal comes from countries which have Portuguese as their mother-tongue, in particular Cape Verde, Angola and Brazil (Serviço de Estrangeiros e Fronteiras, 2016; Pordata, 2017b) Despite the challenges, this immigration has been well integrated in the Portuguese society, including the Muslim community (Público, 2015) Even if we consider other ethnicities/races, the levels of immigration in Portugal raises little to no worries for political leaders. Immigration from Eastern Europe, for example, accounts for 383,759 legal residents in Portugal, a substantial majority that is also well integrated into society (Pordata, 2017b). Prime Minister, António Costa, who has lead the government 
since the parliamentary elections of 2015, stated that from the beginning of 2016 onward, Portugal would be able to accept more than 4000 people requesting asylum, 1250 of them immediately, and if necessary, "overcoming bureaucratic difficulties in European legislation" (as cited in Diário de Notícias, 2016).

\section{Portugal is pro-European union}

Another banner of European right-wing populists has been Eurocepticism, which also finds little support from Portuguese parties and society in general. Concerning the parliamentary representation, only the aforementioned PCP and BE contain Eurosceptic elements in their programs, and they are both leftwing parties. The PCP is economically one of the most orthodox and conservative Communist parties in Europe; and the $\mathrm{BE}$, a more recent party in the Portuguese political spectrum, calls not for Portugal's exit from the European Union, but for reform of the European Union itself (which is, according to BE, very distant from the European citizens). These two parties represented, in the 2015 elections, $18.44 \%$ of the votes. The more pro-European parties, therefore, accounted for $80 \%$ of the parliamentary composition that stem from the 2015 elections.

In addition, according to the Eurobarometer (Eurobarometer 2016), the majority of the Portuguese felt themselves to be European Union citizens (75\%) and "the values of trust in the European Union are more positive for Portugal (43\%)" (Eurobarometer, 2016). An updated version published in early 2017 goes even further and indicates that "Portugal, which was, in the fall of 2013, the European country with the highest levels of dissatisfaction towards the European Union, has now approval rates higher than $50 \%$ and similar to the European average", and that "most Portuguese rejects the idea that the country could have a better future outside the Union" (European Commission, 2017). The reasons behind the strong Portuguese support towards the European Union might be found in a report written by the European Union Commission, which affirms that "for more than half of the Portuguese $[\ldots]$ the free circulation of people, goods and services, and peace among European countries are the two most positive results of the EU"'(European Commission, 2016). We highlight these reasons as especially important for the Portuguese people, as the country has a wide diaspora of around 2.3 million people, mainly settled in other European countries (Observatório da Emigração, 2015). In spite of low approval rates towards the European Union during the financial crisis, these same rates have rebounded since 2014 (European Commission, 2016).

Hence, Eurocepticism has little room to develop in Portugal, and may not be used as populist tool by PNR or any other rightwing group in the country.

\section{The limits of party offer}

The existing parties in Portugal also explain right-wing populists' lack of force. The National Front, UKIP or AfD, which base their discourse whether on immigration or Eurocepticism (or both), were essentially protest parties that, over time, gained sufficient support to threaten the traditional political parties-liberal and pro-European. Their growing voting share happened due to the high flow of immigrants and the sense of general insecurity, accompanied with appeals to the national identity against the supranationalism of the European Union. In Portugal, however, unemployment $(62 \%)$ and the economic situation $(30 \%)$ are the main concerns of the average citizen-a consequence of the financial crisis and the strong austerity measures imposed by the European Commission, IMF, and European Central Bank. In the aftermath of the 2011 crisis, with rising unemployment and falling purchasing power, parties which represented a rupture with the economic program were the ones that grew in importance. Even the Socialist Party (PS) and the Social Democratic Party (PSD), that have been rotating in power for more than 40 years, have not lost their presence on the political scene in the same way the French PS and the Republicans lost in favor of Le Pen; or the Spanish PSOE in favor of Podemos and the Liberals. As André Freire said, there are in Portugal parties for which the Portuguese electorate channels its protest vote: $\mathrm{BE}$ and PCP (Neto et al., 2016). This protest reflects the main concerns of the Portuguese, mostly socio-economic (and not migratory or European).

This phenomenon has led Marco Lisi to stress in 2014 that, "Portugal is experiencing a huge economic and social crisis that has not triggered-at least until now-significant changes in the political system, as it happened in Greece or Italy" (Lisi, 2014, p 229). In other cases in Europe, political disengagement by the citizens has led to higher support for populist parties (see, e.g., Magni, 2017, Goodlife, 2012, Webb, 2013), but the same did not happen in Portugal, in spite of witnessing that same political disengagement. For example, in the parliamentary elections, the abstention rates exceeded $40 \%$ in $2009,41 \%$ in 2011 at the peak of the crisis, and $44 \%$ in 2015 . The withdrawal from the electoral process presents itself as the main response from the disgruntled Portuguese citizens.

Hence, data shows that, in Portugal, political disengagement by citizens does not automatically mean higher support for rightwing populist parties (and specifically to PNR, who has registered continued voting rates in the same period mention above), as shown by high abstention rates allied with an unaltered and unperturbed political system (Lisi, 2014; Raimundo and Pinto, 2014)..$^{3}$

\section{Communicating populism}

A handful of authors have more recently addressed a new aspect of populism, namely the way it communicates its message and influences political opinions and attitudes (Alvares and Dahlgren, 2016; Burack et al. 2012; Hameleers and Schmuck, 2017; Engesser et al., 2017; Krämer, 2017; Higgins, 2017; Hameleers et al., 2017). Populism has, in fact, taken advantage of Internet to spread its message and twist the public opinion since the beginning of Internet's birth (Bimber, 1998), with the purpose of "restructur [ing] political power in a populist direction" (p 143).

It is an insightful perspective, yet requires further research to be fully understood. A set of literature, however, has addressed this issue in several countries in Europe where populist parties have gained some terrain, such as Italy (Lanzane and Woods, 2015), Finland (Herkman, 2017), France (Mondon, 2014; Nilsson, 2015; Williams, 2011), the Netherlands (Bos and Brants, 2014; Pas et al., 2011; Hameleers and Schmuck, 2017), the UK (Cushion et al., 2015; Deacon and Wring, 2016; Reed, 2016), or Sweden (Nilsson and Carlsson, 2014).

In our comment, we only take social media into account because (1) there are around 2.46 billion people social media users worldwide in 2017 (Statista, 2017), (2) social media allows, as mass media tool, "a variety of actors", political included, to become appealing in the eyes of media users (van Dijck and Poell, 2013), and consequently, because (3) "political communications has become dependent on social media for gathering and organizing support, as well as for conveying consistent political slogans and themes" (Higgins, 2017, p 3). Social media has thus been used by right-wing populist parties across Europe to influence citizens in believing in their causes and voting for them.

In Portugal, contrary to Marine Le Pen or Geert Wilders' parties, PNR has only around 30,000 likes on Facebook, and little more than 1300 followers on Twitter. Moreover, its leader José 
Pinto Coelho has around 4600 likes on Facebook and 1300 followers on Twitter. The Party (and the Portuguese far right in general) takes little advantage of social media platforms as a means to influence Portuguese public opinion. TV and newspapers are the most relevant media platforms that PNR uses to communicate its populist message. This situation is more notorious, naturally, during elections, in which Pinto Coelho and PNR are allowed to have more "media space" to communicate their ideas. Social media platforms, however, have fallen behind TV for the Portuguese right-wing populism to influence public opinion. The Party's visibility on social media platforms like Facebook or Twitter may be higher in specific moments such as elections or well-attended political rallies, but apart from that, they have little visibility and influence, and considerably lower than Marine Le Pen, Geert Wilders, or Nigel Farage. These leaders captivate and appeal to a large proportion of their voters through their strategy on social media: whether through emotional messages or through bold and controversial posts and tweets that spark a polemic and fierce debate among civil society (thus bringing even more visibility to their campaigns). Rightwing populists in Portugal, on the other hand, have failed to accomplish any of these goals with their social media strategy.

\section{Conclusion and future prospects}

Portugal has stayed apart from the general rise of right-wing populism in Europe, Right-wing populism has not found the visibility and influence it has in other European countries, and traditional parties have kept their presence in the Portuguese political spectrum. We have brought several hypotheses to the discussion that can help us understand the lack of force of rightwing populism in Portugal. The most relevant are the low immigration rate in the country, and the relatively high levels of political and social identification of the Portuguese population with the European Union. Allied to these two elements, there are other (left-wing) parties, such as BE and PCP, to which the population channels their protest vote-mainly based on socioeconomic reasons, and not securitarian or identitarian. Finally, the Portuguese right-wing populists do not possess the same communication skills on social media that other right-wing populists in Europe, like Marine Le Pen or Geert Wildeers do. These leaders captivate and appeal to most of their voters through their strategy on social media, which José Pinto Coelho and the PNR have not managed to accomplish.

Naturally, some of the dynamics aforementioned may suffer an abrupt change and dissolve this delicate balance that prevents the emergence of right-wing populism in Portugal. A sudden massive influx of immigrants may change the perceptions of the Portuguese population in general, both in terms of national identity or/ and national security (it is highly relevant to point out that, so far, Portugal has not witnessed any terrorist attack on its soil). A potential collapse of the European Union also has the potential to spark the more nationalist portion of the population, especially Eurosceptics represented in part by the far-right PNR. Finally, a more robust and effective communication strategy by right-wing populists in Portugal may also bring more visibility to their cause, and spark more fierce debates among the civil society groups and individuals concerning their national security or identity, or incapacity of the political establishment to represent the "will of the people" as portrayed by Cas Mudde. So far, this balance has not been eroded, and the political system has not changed considerably in favour of right-wing populists. Only the future will test and prove the strength of this stability in Portugal.

The importance of this comment lies on the fact that Portugal has not witnessed right-wing populism resurgences that have threatened its political system, unlike other European countries that are now witnessing it, or have witnessed it several times in previous decades. In a future where faster communication networks, higher levels of migration rates and nativist/authoritarian movements are sweeping Europe and the world, we argue that Portugal is so far an insulated case worthy of analysis.

Received: 17 September 2017 Accepted: 14 December 2017 Published online: 23 January 2018

\section{Notes}

1 Translated by the author.

2 Translated by the author.

3 There are two different scholarly perspectives on how the Portuguese political system has been configuring in the past few years: Marco Lisi (2010) defends that the voting trend is a more fragmented scenario, leading to the end of the majority tendency from previous decades; while others, such as Magalhães (2012) defend that continuity is the most important trend (Raimundo and Pinto 2014, p 4).

\section{References}

Albertazzi D, McDonnell D (2008) Introduction: the Sceptre and the Spectre. In: Albertazzi D, McDonnell D (eds) Twenty-first century populism:The Spectre and the Sceptre. Palgrave, London, p 1-14

Alvares C, Dahlgren P (2016) Populism, extremism and media: mapping an uncertain terrain. Eur J Commun 31(1):46-57

Bimber B (1998) The Internet and political transformation: Populism, community, and accelerated pluralism. Polity 31(1):133-160

Borges, L (2015) Os imigrantes são os mais atingidos pela crise. Mas também são os que mais depressa recuperam. Retrieved from http://www.jornaldenegocios. pt/economia/detalhe/os_imigrantes_sao_os_mais_atingidos_pela_crise_mas_ tambem_sao_os_que_mais_depressa_recuperam

Bos L, Brants K (2014) Populist rhetoric in politics and media: A longitudinal study of the Netherlands. Eur J Political Res 29(6):703-719

Bos L, Brug W,v,d, de Vreese C,d (2013) An experimental test of the impact of style and rhetoric on the perception of right-wing populist and mainstream party leaders. Acta Polit 48(2):192-208

Burack C, Claire Snyder-Hall R (2012) Introduction: right-wing populism and the media. New Polit Sci 34(4):439-454

Cushion S, Thomas R, Ellis O (2015) Interpreting UKIP's "Earthquake" in British politics: UK television news coverage of the 2009 and 2014 EU Election Campaigns. Polit Q 86(2):314-322

Deacon D, Wring D (2016) The UK Independence Party, populism and the British news media: competition, collaboration or containment? Eur J Commun 31 (2):169-184

Diário de Notícias (2016) António Costa garante que Portugal tem disponibilidade "imediata" para acolher 1250 refugiados [António Costa guarantees that Portugal has "immediate" availability to host 1250 refugees]. http://www.dn. $\mathrm{pt} /$ portugal/interior/antonio-costa-garante-que-portugal-temdisponibilidade-imediata-para-acolher-1250-refugiados-5121122.html. Accessed 2 June 2017

Engesser S, Ernst N, Esser F, Büchel F (2017) Populism and social media: how politicians spread a fragmented ideology. Inf Commun Soc 20(8):1109-1126

Eurobarometer (2016) Eurobarómetro-primavera de 2016 [EurobarometerSpring 2016]. https://ec.europa.eu/portugal/news/eurobarometer-spring2016_pt. Accessed 28 May 2017

European Commission (2016) Eurobarómetro Standard 86 [Eurobarometer Standard 86]. Retrieved from https://ec.europa.eu/portugal/sites/portugal/files/ eurobarometro-standard-86-portugal.pdf

European Commission (2017) Portugueses voltam a ter uma perspetiva mais positiva da UE [The Portuguese have once more a positive perspective towards the EU]. Retrieved from https:/ec.europa.eu/portugal/news/ eurobarometer-86-portugal_pt

Expresso (2015) Diretor adjunto do SEF diz que refugiados preferem países do norte europeu [SEF's adjunct director says refugees prefer Northern european countries]. Retrieved from http://expresso.sapo.pt/sociedade/2015-11-27Diretor-adjunto-do-SEF-diz-que-refugiadospreferem-paises-do-norteeuropeu

Freeden M (1996) Ideologies and political theory: a conceptual approach. Oxford University Press, Oxford

Goodlife G (2012) The Price of Disengagement: Radical Populism in France and Germany. Journal of Contemporary European Studies 20(2):137-160

Hameleers M, Bos L, de Vreese CH (2017) The appeal of media populism: the media preferences of citizens with populist attitudes. Mass Commun Soc 20 (4):481-504 
Hameleers M, Schmuck D (2017) It's us against them: a comparative experiment on the effects of populist messages communicated via social media. Inf Commun Soc 20(9):1425-1444

Herkman J (2017) The Finns party: Euroscepticism, EuroCrisis, populism and the media. Media Commun 5(2):1-10

Higgins M (2017) Mediated populism, culture and media form. Palgrave Commun $3(3): 1-5$

Huber RA, Schimpf CH (2017) On the distinct effects of left-wing and right-wing populism on democratic quality. Politics and Governance 5(4):146-165

Jagers J, Walgrave S (2007) Populism as a political communication style: an empirical study of political parties' discourses in Belgium. Eur J Polit Res 46 (3):319-345

Krämer B (2017) Populist online practices: the function of the Internet in rightwing populism. Inf Commun Soc 20(9):1293-1309

Lanzane L, Woods D (2015) Riding the populist web: contextualizing the five star movement (M5S) in Italy. Polit Gov 3(2):54-64

Lisi M (2010) The Renewal of the Socialist Majority: the 2009 Portuguese Legislative Elections. West European Politics 32(2):381-388

Lisi M (2014) Portugal: Between apathy and crisis of mainstream parties. CISE, Rome.

Lucardie P, Voerman G (2012) Populisten in de Polder. Boom, Amsterdam

Magalhães P (2012) After the bailout: Responsibility, Policy, and Valence in the Portuguese Legislative Election of June 2011. South European Society and Politics 17(2):309-327

Magni G (2017) It's the emotions, Stupid! Anger about the economic crisis, low political efficacy, and support for populist parties Electoral Studies 50:91-102

March L (2007) FromVanguard of the Proletariat to Vox Populi: left-populism as a "Shadow" of contemporary socialism. SAIS Rev 27(1):63-77

March L (2011) Radical left parties in Europe. Routledge, London

Marchi R (2013) The extreme right at the dawn of Portuguese democracy. In: Melzer R, Serafin S (eds) Right-wing extremism in Europe: country analyses, counter-strategies and labor-market oriented exit strategies. Friedrich Ebert Foundation, Berlin, p 133-155

Marchi R (2017) Mapa ideológico do nacionalismo português contemporâneo [Ideological map of the contemporary Portuguese nationalism]. https:// ionline.sapo.pt/554240? source=social. Accessed 3 June 2017

Ministério da Administração Interna (2015) Legislativas 2015: Resultados globais. http://www.eleicoes.mai.gov.pt/legislativas2015. Accessed 9 June 2017

Mondon A (2014) The front national in the twenty-first century: from Pariah to republican democratic contender? Mod Contemp Fr 22(3):301-320

Mudde C (2004) The populist zeitgeist. Gov Oppos 39(4):541-563

Mudde C (2007) Populist radical right parties in Europe. Cambridge University Press, Cambridge

Neto OC, Gonçalves LP and Marchi R (2016) Radicalismos na Política-Reflexões com António Costa Pinto e André Freire [Radicalisms in politics-Refelctions with António Costa Pinto and André Freire]. https://repositorio.iscteiul.pt/bitstream/10071/12097/1/24427-99223-2-PB.pdf. Accessed 30 May 2017

Nilsson B, Carlsson E (2014) Swedish politicians and new media: Democracy, identity and populism in a digital discourse. New Media \& Soc 16(4):655-671

Nilsson PE (2015) Secular retaliation: a case study of integralist populism, antimuslim discourse, and (I)liberal discourse on secularism in contemporary France. Polit Relig Ideol 16(1):87-106

Observatório da Imigração (2015) Estimativas e dados globais [Estimates and global data] Retrieved from http://observatorioemigracao.pt/np4/1315/

Otjes S, Louwerse T (2015) Populists in parliament: comparing left-wing and rightwing populism in the Netherlands. Polit Stud 63:60-79

Pas D,v,d, de Vries C, Brug W,v,d (2011) A leader without a party: Exploring the relationship between Geert Wilders' leadership performance in the media and his electoral success. Part Polit 19(3):458-476

Pereira S, Esteves, A (2017) Os efeitos da crise económica na situação laboral dos imigrantes: o caso dos brasileiros em Portugal [The effects of the economic crisis on the labour market situation of immigrants: the case of Brazilians in Portugal]. REMHU, Rev Interdiscip Mobil Hum 25:135-152

Pordata (2017a) Taxa bruta de imigração—Europa [Gross immigration rate—Europe]. https://www.pordata.pt/Site/MicroPage.aspx?DatabaseName=Europa\&Micro
Name $=$ Taxa + bruta + de+imigra\%C3\%A7\%C3\%A3o\&MicroURL=1934\&. Accessed 27 May 2017

Pordata (2017b) População estrangeira com estatuto legal de residente: total e por algumas nacionalidades-Portugal [Foreign population with legal resident status: Total and by nationality-Portugal]. https://www.pordata.pt/Site/ MicroPage.aspx?DatabaseName=Portugal\&MicroName=Popula\%C3\%A7\% $\mathrm{C} 3 \% \mathrm{~A} 3 \mathrm{o}+$ estrangeira+com+estatuto+legal+de+residente+total+e+por+algumas+nacionalidades\&MicroURL $=24 \&$. Accessed 27 May 2017

Público (2015) São portugueses, são muçulmanos [They are P-ortuguese, they are Muslim]. https://www.publico.pt/2015/02/08/sociedade/noticia/saoportugueses-sao-muculmanos-1685260. Accessed 13 June 2017

Público (2016) Os novos imigrantes de Portugal são sobretudo da Europa Ocidental [New immigrants in Portugal are mostly from Western Europe] Retrieved from https://www.publico.pt/2016/06/23/sociedade/noticia/osnovos-imigrantes-de-portugal-sao-sobretudo-da-europaocidental-1735969

Raimundo, F, and Pinto, AC (2014) When parties succeed: party system (in) stability and the 2008 financial crisis in Portugal. Paper prepared for delivery at the 2014 Annual Meeting of the American Political Science Association, Washington, DC, 28-31 August 2014

Reed M (2016) This loopy idea-an analysis of UKIP's social media discourse in relation to rurality and climate change. Space Polit 20(2):226-241

Serviço de Estrangeiros e Fronteiras (2016) Relatório de Imigração, Fronteiras e Asilo [Report on immigration, borders and asylum]. Retrieved from https:// sefstat.sef.pt/Docs/Rifa2016.pdf

Stanley B (2008) The thin ideology of populism. J Polit Ideol 13(1):95-110

Statista (2017) Number of social media users worldwide from 2010 to 2021 (in billions). Retrieved from https://www.statista.com/statistics/278414/numberof-worldwide-social-network-users/

Taggart P (2000) Populism. Open University Press, Buckingham

van Dijck J, Poell T (2013) Understanding Social Media Logic. Media and Communication 1(1):2-14

Webb P (2013) Who is willing to participate? Dissatisfied democrats, stealth democrats and populists in the United Kingdom. Eur J Political Res 52 (6):747-772

Williams M,H (2011) A new era for French far right politics? Comparing the FN under two Le Pens. Análise Soc XLVI:679-695

\section{Additional information}

Competing interests: The author declares no competing financial interests.

Reprints and permission information is available online at http://www.nature.com/ reprints

Publisher's note: Springer Nature remains neutral with regard to jurisdictional claims in published maps and institutional affiliations.

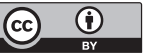

Open Access This article is licensed under a Creative Commons Attribution 4.0 International License, which permits use, sharing, adaptation, distribution and reproduction in any medium or format, as long as you give appropriate credit to the original author(s) and the source, provide a link to the Creative Commons license, and indicate if changes were made. The images or other third party material in this article are included in the article's Creative Commons license, unless indicated otherwise in a credit line to the material. If material is not included in the article's Creative Commons license and your intended use is not permitted by statutory regulation or exceeds the permitted use, you will need to obtain permission directly from the copyright holder. To view a copy of this license, visit http://creativecommons.org/ licenses/by/4.0/.

(C) The Author(s) 2018 